\title{
Leader Purposefulness within Servant Leadership: Examining the Effect of Servant Leadership, Leader Follower-Focus, Leader Goal-Orientation, and Leader Purposefulness in a Large U.S. Healthcare Organization
}

\author{
Justin A. Irving ${ }^{1, *}$ and Julie Berndt ${ }^{2}$ \\ 1 Doctor of Ministry Department, Bethel University, 3900 Bethel Drive, St. Paul, MN 55112, USA \\ 2 The Evangelical Lutheran Good Samaritan Society, 4800 West 57th Street, Sioux Falls, SD 57108, USA; \\ jberndt@good-sam.com \\ * Correspondence: j-irving@bethel.edu
}

Academic Editors: Dirk van Dierendonck and Kathleen A. Patterson

Received: 11 January 2017; Accepted: 26 April 2017; Published: 5 May 2017

\begin{abstract}
As the study of servant leadership expands beyond theoretical exploration, empirical research continues to validate the positive effect of servant leadership behaviors and attitudes on diverse follower and organizational measures. This study expands the conversation by engaging the theme of leader purposefulness within servant leadership studies. A sample of over 1700 employees from a large U.S. healthcare organization provided responses to five research instruments. Follower perspectives on servant leadership, leader follower-focus, leader goal-orientation, and leader purposefulness were assessed using the Purpose in Leadership Inventory and each of these independent variables were analyzed for hypothesized positive relationships with four dependent variables: follower job satisfaction, follower organizational commitment, follower person-organization fit, and follower perception of leadership effectiveness. Each of the 16 hypothesized relationships were supported at a statistically significant level $(<0.001)$ with positive correlations ranging from 0.40 to 0.88 . Regression analyses were conducted to provide predictive modeling and indicators of the relative importance of each independent variable on the related dependent variables.
\end{abstract}

Keywords: servant leadership; leader purposefulness; leadership measurement; job satisfaction; organizational commitment; person organization fit; goal orientation; follower focus; meaning; spiritual leadership

\section{Introduction}

The study of servant leadership continues to gain attention in the scholarly literature. Based on the early conceptual work of Robert K. Greenleaf [1], leadership theorists began to engage the work of theory formation in the 1990s and early 2000s, and this has given rise to empirical studies through to today. Although early conceptual and theoretical work connected servant leadership to themes related to purpose and meaning, most empirical work on the effect of meaning and purpose has been disconnected from the servant leadership literature. In the literature review within this article, the authors argue that leader purposefulness is related to the study of servant leadership and should be included as a dimension of servant leadership research and theory. This study aims to position leader purposefulness as part of servant leadership. 
Based on this review, the researchers examine the following primary research question: Does the Purpose in Leadership Inventory [2], both its composite measure of servant leadership and its subscales (leader follower-focus, leader goal-orientation, and leader purposefulness), evidence criterion validity with important work-related outcomes? In a previous study [2], the reliability and factor structure of the Purpose in Leadership Inventory (PLI) was examined. This study adds to the former study by examining the criterion validity of the instrument. The PLI adds to other existing servant leadership instruments by providing a means for studying leader purposefulness as an explicit dimension of servant leadership. Further examining the PLI for criterion validity will help demonstrate the validity of the measure.

Toward the aim of answering this research question, the researchers examine the relationship between four leader independent variables and four dependent variables in order to assess the relationship between dimensions of a leader's servant leadership focus and the effect of these dimensions on followers. Follower perspectives on servant leadership, leader follower-focus, leader goal-orientation, and leader purposefulness were assessed using the Purpose in Leadership Inventory [2]. Each of these independent variables was analyzed for hypothesized positive relationships to four dependent variables: follower job satisfaction, follower organizational commitment, follower person-organization fit, and follower perception of leadership effectiveness. Regression analyses were conducted to provide predictive modeling and indicators of the relative importance of each independent variable on the related dependent variables. Special focus was given to the unique and incremental value of leader purposefulness.

This study and the related findings aim to provide additional empirical evidence that both validates the important impact of servant leadership on organizational members and expands the conversation of servant leadership to include leader purposefulness in light of the positive relationship of leader purposefulness on the same dependent variables of follower job satisfaction, follower organizational commitment, follower person-organization fit, and follower perception of leadership effectiveness. In the discussion of the literature that follows, servant leadership and leader purposefulness are engaged in separate sections. However, the authors see these not as distinct variables, but rather leader purposefulness as a dimension of servant leadership. As such, the PLI is used to both measure leader follower-focus, leader goal-orientation, and leader purposefulness independently and as a composite measure of servant leadership.

\section{Servant Leadership}

The study of leadership in contemporary history evidences a shift from leader-centered models to follower-considerate approaches such as transformational leadership theory and servant leadership theory. On this point, Matteson and Irving write that such theories represent, "an important step toward balancing the needs of both leaders and followers as they work toward fulfilling organizational goals" [3] (p. 36). Although attention to organizational outcomes has dominated managerial and leadership theory in the early part of the twentieth century, servant leadership elevates the priority of focusing on follower needs.

For Greenleaf, "the servant leader is servant first," and is a person who takes care "to make sure that other people's highest priority needs are being served" [1] (p. 27). This spirit of follower focus identified by Greenleaf is named by others as the distinguishing characteristic of servant leadership. On this point, Stone et al. argue that servant leaders, "focus on the followers and the achievement of organizational objectives is a subordinate outcome" [4] (p. 349). Such arguments do not diminish the importance of leaders attending to organizational goals and outcomes. Rather, these arguments emphasize that the primary means by which outcomes are achieved is through prioritizing focus on and service of followers. As followers become the focus of leaders, and are served by these leaders, followers become the primary agents by which organizational goals are met.

Related to this discussion, Gibson and Birkinshaw [5] and Sun [6] identify the need for balancing social-context and performance-context as both the people of the organization and the outcomes of the 
organization are considered. Irving [2] sought to bring these two threads of follower focus and goal orientation together at the individual leader level through an instrument that measures purposeful servant leader orientation. Incorporating such elements into the Purpose in Leadership Inventory, Irving [2] argues that servant leaders are characterized by personal purpose, and are oriented toward both the purposes of follower focus and goal orientation. While there is a tendency to see goal focus and follower focus at odds $[7,8]$, others support the importance of servant leaders holding these two areas of focus together in servant leadership practice $[2,6,9]$. Regarding this point, Van Dierendonck and Nuijten argue that servant leadership measures need to give attention to both the 'servant' and the 'leader' dimensions of servant leadership. While the servant dimension emphasizes the people aspect, the leader dimension is about giving direction. The aspects of follower focus and goal orientation in Irving's measure provide such balance in a measurement instrument.

From Greenleaf's [1] early work, servant leadership studies slowly moved from the work of theory formation $[4,10])$ to the development and use of empirical research instruments measuring the construct $[2,9,11-16]$. Servant leadership instruments have been used to examine the effect of servant leadership on diverse dependent variables such as job satisfaction [11,17-20], organizational citizenship behavior [21,22], team performance [23,24], and firm performance [25]. This growing body of empirical research demonstrates the value of servant leadership not only as a positive ideal, but also as an effective approach to leadership practice.

\section{Leader Purposefulness}

The theme of purpose has been part of the organizational leadership literature for many years. For example, Collins and Porras [26] argue for the importance of purpose at an organizational level, and note that purpose is a natural outgrowth of an organization's core values and beliefs that provides a motivating factor for organizational members. Rather than organizations needing to set or create purpose, Collins and Porras argue that organizations must simply recognize or discover the purpose that is already present.

The concept of leader purposefulness engaged in this study expands beyond the organizational level to include discussion of the individual leader level as well. Albrecht writes: "Those who would aspire to leadership roles in this new environment must not underestimate the depth of this human need for meaning. It is a most fundamental human craving, an appetite that will not go away" [27] (p. 22).

Similarly, Fry writes that it is well established that, "almost universally, people have the intrinsic drive and motivation to learn and find meaning in their work," including the work of leadership [28] (p. 702). Affirming the value of purpose in light of servant leadership, Bordas reflects on Greenleaf's essay "The Servant as Leader." On this point, Bordas writes, "Just as the servant-leader is 'servant first' and begins with a 'natural feeling that one wants to serve,' seeking the guidance of personal purpose begins with the desire to connect with the 'greatest good,' both within oneself and society" [29] (p. 180).

In his discussion of authentic leadership, George [30] identifies leader purpose as one of five core dimensions of authentic leadership. For George, this is not simply about a leader adopting the purpose of an organization or another individual, but rather understanding and embracing his or her particular purpose. Bordas makes a similar argument: "A person cannot adopt the purpose of another, each must find his or her own" [29] (p. 181). Such arguments affirm that purpose is not just an organizational level issue [26], but also a matter for leaders to take seriously at the individual level. On this point George writes: "Without a real sense of purpose, leaders are at the mercy of their egos and are vulnerable to narcissistic impulses. There is no way you can adopt someone else's purpose and still be an authentic leader. You can study the purposes others pursue and you can work with them in common purposes, but in the end the purpose for your leadership must be uniquely yours" [30] (p. 19).

In addition to the emphasis on purpose found in the authentic leadership thread, meaning-centered approaches to leadership and management reinforce the importance of purpose for leaders [31-33]. Complementing these emphases, other authors engage the importance of 
purpose, meaning, and leadership in the context of the workplace [34-38]. Although most of the above-noted sources argue for the value of leaders possessing a sense of purpose and meaning, these arguments are largely theoretical in nature, thus supporting the value of further empirical study on leader purposefulness.

Evaluating the development of leadership theory over the past century evidences the presence of purpose and meaning in early conceptualizations. For example, Podolny et al. [39] highlight their concern around leadership research going awry when leadership began to be decoupled from the notion of meaning. As performance became more prominent than meaning, performance was largely separated from broader ideals. In light of this, Podolny et al. argue for economic performance and the meaningfulness of work to be brought back together as leadership studies return to their roots related to purpose. Some of these roots, argue Podolny et al., are found in theorists such as Max Weber where "leadership was deemed as important because of its capacity to infuse purpose and meaning into the lives of individuals" [39] (p. 69).

Also related to leader purposefulness is the discussion of spiritual leadership $[28,40,41]$. Markow and Klenke [42] argue that meaning and purpose are embedded in a number of definitions of spirituality. Examples of this include Tepper [43], Cash and Gray [44], and Zinnbauer et al. [45]. Connected to Maddock and Fulton's [46] as well as Fleischman's [47] discussion of calling, Fry sees purpose as closely tied to calling. On this point Fry writes, "Calling refers to the experience of transcendence or how one makes a difference through service to others and, in doing so, derives meaning and purpose in life" [28] (p. 703). For Fry, calling is both about making a difference and life having meaning.

As leadership theories that engage the discussion of purpose, it is important to recognize points of connection between spiritual leadership and servant leadership. This is identified by Fry [41] in noting the connections between spiritual leadership theory and values-based leadership theories such as authentic leadership and servant leadership. Additionally, Sendjaya [15] and Freeman [48] provide extended discussions regarding the connection between spirituality and servant leadership. Freeman argues that spirituality is the motivational basis for servant leaders engaging others. Sendjaya argues that both servant leadership and spiritual leadership models "appeal to virtuous leadership practices and intrinsic motivating factors to cultivate a sense of meaning, purpose, and interconnectedness" [15] (p. 404).

Conceptually bringing the above themes together, Irving reports on the development and validation of the Purpose in Leadership Inventory (PLI) [2]. The PLI provides a path for studying leader purposefulness as a dimension of servant leadership. The instrument measures overall servant leadership, as well as leader purposefulness, goal orientation, and follower focus as dimensions of servant leadership. Collectively, these scales provide a means for measuring servant leadership as a single variable. Focus on and service of followers is arguably the distinguishing characteristic of servant leadership practice $[1,4,10,15]$. As a validated and reliable instrument measuring the presence of leader purposefulness, the PLI provides a pathway for addressing some of the concerns identified by Podolny et al. [39], and places the dimensions of purpose and meaning identified by George [30], Wong [31], and Wong and Fry [31] into a research instrument that may be used to measure leader purposefulness within the conceptual frame of servant leadership. Due to its emphasis on purposefulness in servant leadership, and the inclusion of measures of goal orientation and follower focus, the PLI is one of the instruments used in the present study.

\section{Study Hypotheses}

The study includes four primary hypotheses: (1) that the overall servant leadership (SL) of a leader will positively relate to follower organizational commitment (OC); (2) that SL will positively relate to follower overall job satisfaction (JS); (3) that SL will positively relate to follower perceived person-organization fit (POF); and (4) that SL will positively relate to follower perception of leadership effectiveness (LE). These four primary hypotheses are identified as hypotheses 1A, 2A, 3A, and 4A in 
Table 1 below. Because the researchers are interested in the effect of both the composite measure of servant leadership and the effect of the subscales in the PLI, three additional hypotheses are examined in relationship to these four primary hypotheses. Each of the sub-hypotheses are presented below in light of each dependent variable.

Table 1. Findings for Study Hypotheses.

\begin{tabular}{cc}
\hline Hypothesis & Hypothesized Relationship \\
\hline & Hypotheses Related to Organizational Commitment (OC) \\
\hline Hypothesis 1A & Servant Leadership (SL) will positively relate to OC \\
Hypothesis 1B & Leader Follower-Focus (FF) will positively relate to OC \\
Hypothesis 1C & Leader Goal-Orientation (GO) will positively relate to OC \\
Hypothesis 1D & Leader Purposefulness (LP) will positively relate to OC \\
\hline & Hypotheses Related to Job Satisfaction (JS) \\
\hline Hypothesis 2A & Servant Leadership will positively relate to JS \\
Hypothesis 2B & Leader Follower-Focus will positively relate to JS \\
Hypothesis 2C & Leader Goal-Orientation will positively relate to JS \\
Hypothesis 2D & Leader Purposefulness will positively relate to JS \\
\hline & Hypotheses Related to Person-Organization Fit (POF) \\
\hline Hypothesis 3A & Servant Leadership will positively relate to POF \\
Hypothesis 3B & Leader Follower-Focus will positively relate to POF \\
Hypothesis 3C & Leader Goal-Orientation will positively relate to POF \\
Hypothesis 3D & Leader Purposefulness will positively relate to POF \\
\hline & Hypotheses Related to Leadership Effectiveness (LE) \\
\hline Hypothesis 4A & Servant Leadership will positively relate to LE \\
Hypothesis 4B & Leader Follower-Focus will positively relate to LE \\
Hypothesis 4C & Leader Goal-Orientation will positively relate to LE \\
Hypothesis 4D & Leader Purposefulness will positively relate to LE \\
\hline
\end{tabular}

\subsection{Hypotheses Related to Organizational Commitment}

In previous studies, researchers found servant leadership to have a positive effect on organizational commitment (e.g., [9,16,49-52]). Making an argument from social exchange theory, Liden et al. [16] note that the connection between servant leadership and follower organizational commitment is likely explained by subordinate motivation to respond with extra commitment based on the example of extra effort modeled by servant leaders. Based on the related empirical literature, the researchers hypothesize that servant leadership, as measured by the PLI, will positively relate to organizational commitment $\left(\mathrm{H}_{1 \mathrm{~A}}\right)$. Additionally, as dimensions of servant leadership, the researchers argue that leader follower-focus, leader goal-orientation, and leader purposefulness will also positively relate to organizational commitment $\left(\mathrm{H}_{1 \mathrm{~B}}, \mathrm{H}_{1 \mathrm{C}}\right.$, and $\left.\mathrm{H}_{1 \mathrm{D}}\right)$.

\subsection{Hypotheses Related to Job Satisfaction}

Job satisfaction is frequently examined in the empirical literature for its relationship with servant leadership practices. In previous studies, researchers found servant leadership to have a positive effect on job satisfaction (e.g., [9,11,17-20,49,52,53]). Based on this empirical literature, the researchers hypothesize that servant leadership, as measured by the PLI, will positively relate to job satisfaction $\left(\mathrm{H}_{2 \mathrm{~A}}\right)$. Additionally, as dimensions of servant leadership, the researchers argue that leader follower-focus, leader goal-orientation, and leader purposefulness will also positively relate to job satisfaction $\left(\mathrm{H}_{2 \mathrm{~B}}, \mathrm{H}_{2 \mathrm{C}}\right.$, and $\left.\mathrm{H}_{2 \mathrm{D}}\right)$.

\subsection{Hypotheses Related to Person-Organization Fit}

Among the dependent variables included in the present study, person-organization is only seen in the literature in a limited manner. One example of this is in Jaramillo et al. [54] . In their study, the researchers found a positive relationship between servant leadership and person-organization 
fit (0.66). Other studies included person-organization fit as a mediating variable $[55,56]$ in their discussions of servant leadership. The measure used in this study for person-organization fit [57] emphasizes the fit of values between the organizational member and their organization. Because the present study is examining servant leadership with an emphasis on follower-perspectives of leader values (see items of the PLI [2]), the emphasis on value match in person-organization fit will arguably be influenced by leaders leading in a manner consistent with their values and commitments. In light of this, the researchers hypothesize that servant leadership, as measured by the PLI, will positively relate to person-organization fit $\left(\mathrm{H}_{3 \mathrm{~A}}\right)$. Additionally, as dimensions of servant leadership, the researchers argue that leader follower-focus, leader goal-orientation, and leader purposefulness will also positively relate to person-organization fit $\left(\mathrm{H}_{3 \mathrm{~B}}, \mathrm{H}_{3 \mathrm{C}}\right.$, and $\left.\mathrm{H}_{3 \mathrm{D}}\right)$.

\subsection{Hypotheses Related to Leadership Effectiveness}

Providing an empirical rationale for the relationship between servant leadership and leadership effectiveness, Hale and Fields [58] examined the extent to which students perceived a servant leader to be an effective leader among both U.S. and Ghanaian students. Engaging listening as a theme utilized within the context of servant leadership studies, Kramer [59] and Bechler and Johnson [60] found a relationship between listening and leadership effectiveness. Additionally, evidencing the convergent validity of the PLI as a measure of servant leadership, Irving [2] found that leadership effectiveness correlated with the servant leadership practices of leader follower-focus $(0.84)$, leader goal-orientation (0.68), and leader purposefulness (0.69). Based on this empirical literature, the researchers hypothesize that servant leadership, as measured by the PLI, will positively relate to leadership effectiveness $\left(\mathrm{H}_{4 \mathrm{~A}}\right)$. Additionally, as dimensions of servant leadership, the researchers argue that leader follower-focus, leader goal-orientation, and leader purposefulness will also positively relate to organizational commitment $\left(\mathrm{H}_{4 \mathrm{~B}}, \mathrm{H}_{4 \mathrm{C}}\right.$, and $\left.\mathrm{H}_{4 \mathrm{D}}\right)$.

\section{Study Methods}

\subsection{Study Participants}

The organization utilized in this study is a faith-based healthcare system. Servant leadership has been identified in similar organizations as an effective leadership approach [61]. The participants in this study provided their follower assessment of a leader around several leader measures of servant leadership and their own experience of job satisfaction, organizational commitment, person-organization fit, and follower perception of leadership effectiveness.

Over 1780 participants participated in the study, and 1713 participants provided complete responses that could be used for most study analyses. The invitation to participate was sent to around 5000 employees, and each of the employees in this pool had equal opportunity to respond to the invitation during the one-month data collection period. A majority of the participants were in their $40 \mathrm{~s}(23 \%)$ and $50 \mathrm{~s}(31 \%)$, with a significant number of participants also in their $20 \mathrm{~s}(11 \%), 30 \mathrm{~s}$ $(19 \%)$, and 60 s or older $(15 \%)$. A majority of participants were female $(83 \%)$. A majority of participants had either completed Bachelors-level work (33\%), Associates-level work (24\%), or Some College $(23 \%)$. Other educational levels represented single-digit percentages: High School (9\%), Masters (8\%), and Doctorate $(1 \%)$. The length of employment among the participants varied: Less than 1 year $(13 \%)$, $1-5$ years (33\%), $5-10$ years (19\%), $10-15$ years $(11 \%), 15-20$ years $(9 \%)$, and more than 20 years $(15 \%)$.

Relevant information was also gathered for the leaders being assessed by their followers in this study. In terms of years of leadership experiences, most leaders had more than 10 years of leadership experience (48\%), while other leaders were described as having 5-10 years of leadership experience (21\%), 1-5 years of leadership experience (24\%), and less than 1 year of leadership experience $(6 \%)$. Participants were also asked how long this person had been their leader, and responded in the following manner: less than 1 year (33\%), 1-5 years ( $46 \%), 5-10$ years $(14 \%)$, and more than 10 years $(7 \%)$. The sex of the leader was reported as $65 \%$ female and $35 \%$ male. 


\subsection{Study Instruments}

Several research instruments were employed to examine the relationship between servant leadership behaviors and follower job satisfaction, follower organizational commitment, follower person-organization fit, and follower perception of leadership effectiveness. The servant leadership measure utilized was Irving's [2] Purpose in Leadership Inventory (PLI), which provides an overall measure of servant leadership (SL) and subscales measuring leader follower-focus (FF), leader goal-orientation (GO), leader purposefulness (LP). As noted above, leader follower-focus, leader goal-orientation, and leader purposefulness are being studied here as dimensions of servant leadership. In the present study, the reliability coefficients were 0.98 (FF), 0.96 (GO), and 0.97 (LP). Taking all of the items together as a collective measure of servant leadership (SL), the reliability coefficient in the current study was 0.98. Items were scored on a six-point scale ranging from strongly disagree to strongly agree. Irving's exploratory factor analysis on the PLI supports using the PLI as a three-scale instrument [2]. Though not the main focus of the present study, an additional factor analysis was conducted. Details on the present study's factor analysis are reported in the results section below. High reliability coefficients in the former study, and the present study, point toward the value of utilizing the PLI as a collective measure of servant leadership. All items from the PLI are provided in Irving's article [2]. Example items are provided in Table 2.

Table 2. Example PLI Items [2]. Please respond to the following items based on the degree to which the statement characterizes your leader.

\begin{tabular}{|c|c|c|c|c|c|c|}
\hline & $\begin{array}{l}\text { Strongly } \\
\text { Disagree }\end{array}$ & Disagree & $\begin{array}{l}\text { Somewhat } \\
\text { Disagree }\end{array}$ & $\begin{array}{l}\text { Somewhat } \\
\text { Agree }\end{array}$ & Agree & $\begin{array}{c}\text { Strongly } \\
\text { Agree }\end{array}$ \\
\hline $\begin{array}{l}\text { My leader is focused on the needs } \\
\text { of followers. }\end{array}$ & 0 & 0 & 0 & 0 & 0 & 0 \\
\hline $\begin{array}{l}\text { My leader is able to stay focused on } \\
\text { organizational goals. }\end{array}$ & 0 & 0 & 0 & 0 & 0 & 0 \\
\hline $\begin{array}{l}\text { My leader believes that what our } \\
\text { organization does matters. }\end{array}$ & 0 & 0 & 0 & 0 & 0 & 0 \\
\hline
\end{tabular}

In addition to the independent variables measured by the PLI, four dependent variables were utilized in the current study. First, Cammann et al.'s [62] assessment of overall job satisfaction (JS) was utilized. In the present study, the reliability coefficient was 0.86. Second, Balfour and Wechsler's [63] measure of organizational commitment (OC) was utilized. In the present study, the reliability coefficient was 0.90. Third, Cable and Judge's [57] measure of perceived person-organization fit (POF) was utilized. In the present study, the reliability coefficient was 0.84. Finally, Ehrhart and Klein's [64] measure of leadership effectiveness was utilized. As noted later in the study limitations, although the leadership effectiveness scale was utilized, two items were omitted due to an error in inputting the items into the online survey platform. In the present study, the reliability coefficient for the shortened scale was 0.88 .

\subsection{Data Collection}

The instruments were made available to study participants electronically through Qualitrics (www.qualitrics.com). The invitation was extended to around 5000 employees of the organization. The instrument provides a pathway for providing anonymous feedback on the leader to whom the research participant reported on the job, and each of the 5000 employees had equal opportunity to participate in the study. With 1713 usable responses, this random sample represents a sample size from which statistical generalizations may be made to the larger organization [65]. A period of one month was provided for responses, and then the survey was closed to participants. After that time, the data was downloaded into an SPSS file, and SPSS version 22 was used for statistical analysis. 


\subsection{Data Analysis}

Using SPSS version 22, the reliability coefficients were calculated for each of the scales used in the study: (1) leader servant leadership; (2) leader purposefulness; (3) leader follower-focus; (4) leader goal-orientation; (5) follower organizational commitment; (6) follower job satisfaction; (7) follower person-organization fit; and (8) follower perception of leadership effectiveness. An exploratory factor analysis was conducted on the PLI in order to provide construct validity to the measure for the study independent variables. Additionally, two-tailed Pearson $r$ correlations where calculated for each of the intercorrelations between the above variables so that the hypothesized positive relationships noted in Table 1 may be evaluated. After identifying positive correlations, a series regression analyses were conducted in order to provide predictive modeling and indicators of the relative importance of each independent variable on the related dependent variables.

\section{Results}

\subsection{Results for the Purpose in Leadership Inventory (PLI) Factor Analysis}

Though not the main focus of the present study, an exploratory factor analysis was conducted on the Purpose in Leadership Inventory. For this study, the researchers utilized a similar process as Irving's [2] exploratory factor analysis. A Kaiser-Meyer-Olkin (KMO) measure of sampling adequacy and Bartlett's test of sphercity were used. For these, a KMO value of $>0.8$ and a Bartlett's significance value of $<0.05$ was used as a basis for the study. Eigenvalues were analyzed and included when $>1.0$. A principal component extraction method was utilized along with an Oblimin rotation method, and a minimum of $60 \%$ total variance was used as a basis in the present study. Additionally, reliability coefficients were analyzed with a $>0.70$ standard set, and coefficient factor loadings in the factor analysis were suppressed when $<0.30$.

After the analysis, including the suppression of coefficient factor loadings $<0.30$, a 22 -item model yielded nine items for follower-focus, seven items for goal-orientation, and six items for leader purposefulness. The original PLI [2] has 24 items. Due to an error in inputting the items into Qualtrics, only 22 of the 24 items were included in the study. The two omitted items included one item from the goal-orientation subscale and one item from the leader purposefulness subscale. For this 22-item solution, the three factors each had eigenvalues greater than 1.1 (1.0 was set as a minimum) and explained $86.17 \%$ ( $60 \%$ was set as the minimum) of the cumulative variance (See Table 3$)$.

Table 3. The 22-Item Solution.

\begin{tabular}{lccc}
\hline \multirow{2}{*}{\multicolumn{1}{c}{ Component }} & \multicolumn{3}{c}{ Initial Eigenvalues } \\
\cline { 2 - 4 } & Total & \% of Variance & Cumulative \% \\
\hline 1. Follower-Focus & 16.40 & 74.56 & 74.56 \\
2. Goal-Orientation & 1.39 & 6.33 & 80.89 \\
3. Purpose-in-Leadership & 1.16 & 5.28 & 86.17 \\
\hline
\end{tabular}

This solution had a KMO value of 0.979 (0.8 was set as a minimum) and a Bartlett's test of sphericity significance value of 0.000 ( 0.05 was set as a maximum). See Table 4 .

Table 4. KMO and Bartlett's Test.

\begin{tabular}{lcc}
\hline Kaiser-Meyer-Olkin Measure of Sampling Adequacy & $\mathbf{0 . 9 7 9}$ \\
\hline \multirow{3}{*}{ Bartlett's Test of Sphericity } & Approx. Chi-Square & $57,417.52$ \\
\cline { 2 - 3 } & $\mathrm{df}$ & 231 \\
\cline { 2 - 3 } & Sig. & 0.000 \\
\hline
\end{tabular}


Additionally, each of the subscales of the PLI had reliability coefficients greater than the 0.70 minimum set ( 0.98 for FF, 0.97 for GO, 0.96 for LP, and 0.98 for SL). Table 5 provides an overview of the pattern matrix for the 22-item solution based upon a principal component analysis extraction method and an Oblimin with Kaiser Normalization rotation method.

Table 5. Pattern Matrix for 22-Item Solution.

\begin{tabular}{cccc}
\hline & \multicolumn{2}{c}{ Pattern Matrix Components } \\
\cline { 2 - 3 } & 1. Follower-Focus & 2. Goal Orientation & 3. Purpose-in-Leadership \\
\hline Follower-Focus-1 & 0.889 & \\
Follower-Focus-2 & 0.904 & \\
Follower-Focus-3 & 0.977 & \\
Follower-Focus-4 & 0.952 & \\
Follower-Focus-5 & 0.922 & \\
Follower-Focus-6 & 0.862 & \\
Follower-Focus-7 & 0.854 & \\
Follower-Focus-8 & 0.887 & & \\
Follower-Focus-9 & 0.808 & 0.938 \\
Goal-Orientation-1 & & 0.917 & \\
Goal-Orientation-2 & & 0.906 \\
Goal-Orientation-3 & & 0.717 & \\
Goal-Orientation-4 & & 0.901 & \\
Goal-Orientation-5 & & 0.649 & \\
Goal-Orientation-6 & & 0.894 \\
Goal-Orientation-7 & & & 0.952 \\
Leader Purposefulness-1 & & & 0.963 \\
Leader Purposefulness-2 & & & 0.939 \\
Leader Purposefulness-3 & & & 0.901 \\
Leader Purposefulness-4 & & & 0.738 \\
Leader Purposefulness-5 & & & 0.533 \\
Leader Purposefulness-6 & & & \\
\hline
\end{tabular}

\subsection{Results for Hypothesized Relationships}

A matrix of intercorrelations was used to evaluate study hypotheses identified in Table 1. This matrix is provided in Table 6.

Table 6. Matrix of Intercorrelations $(N=1713)$.

\begin{tabular}{lcccccccccc}
\hline \multicolumn{1}{c}{ Measure and Reliability } & Mean & SD & $\mathbf{1}$ & $\mathbf{2}$ & $\mathbf{3}$ & $\mathbf{4}$ & $\mathbf{5}$ & $\mathbf{6}$ & $\mathbf{7}$ & $\mathbf{8}$ \\
\hline 1. Servant Leadership (0.98) & 4.76 & 1.05 & - & & & & & & \\
2. Follower-Focus (0.98) & 4.63 & 1.22 & 0.96 & - & & & & & \\
3. Goal-Orientation (0.97) & 4.64 & 1.15 & 0.92 & 0.81 & - & & & & \\
4. Leader Purposefulness (0.96) & 5.11 & 0.95 & 0.91 & 0.82 & 0.77 & - & & & \\
5. Org. Commitment (0.90) & 4.53 & 0.91 & 0.60 & 0.58 & 0.54 & 0.54 & - & & \\
6. Job Satisfaction (0.86) & 5.07 & 0.88 & 0.45 & 0.43 & 0.41 & 0.40 & 0.71 & - & & \\
7. Person-Org. Fit (0.84) & 3.72 & 0.68 & 0.45 & 0.42 & 0.43 & 0.42 & 0.70 & 0.55 & - & - \\
8. Leadership Effect (0.88) & 4.60 & 1.00 & 0.87 & 0.88 & 0.78 & 0.75 & 0.59 & 0.47 & 0.46 & - \\
\hline
\end{tabular}

All correlations are two-tailed and significant at the level of $<0.001$.

Based on this analysis, statistically significant positive relationships support each of the four primary hypotheses (servant leadership and the four dependent variables) and each of the sub-hypotheses (PLI subscales and the four dependent variables). An overview of this support is provided in Table 7. 
Table 7. Findings for Study Hypotheses *.

\begin{tabular}{cccc}
\hline Hypothesis & Hypothesized Relationship & Pearson $\boldsymbol{r}$ (Sig. 0.000) & Conclusion \\
\hline & Hypotheses Related to Organizational Commitment & \\
\hline Hypothesis 1A & SL will positively relate to OC & 0.60 & $\mathrm{H}_{1 \mathrm{~A}}$ Supported \\
Hypothesis 1B & FF will positively relate to OC & 0.58 & $\mathrm{H}_{1 \mathrm{~B}}$ Supported \\
Hypothesis 1C & GO will positively relate to OC & 0.54 & $\mathrm{H}_{1 \mathrm{C}}$ Supported \\
Hypothesis 1D & LP will positively relate to OC & 0.54 & $\mathrm{H}_{1 \mathrm{D}}$ Supported \\
\hline \multicolumn{5}{c}{ Hypotheses Related to Job Satisfaction } & \\
\hline Hypothesis 2A & SL will positively relate to JS & 0.45 & $\mathrm{H}_{2 \mathrm{~A}}$ Supported \\
Hypothesis 2B & FF will positively relate to JS & 0.43 & $\mathrm{H}_{2 \mathrm{~B}}$ Supported \\
Hypothesis 2C & GO will positively relate to JS & 0.41 & $\mathrm{H}_{2 \mathrm{C}}$ Supported \\
Hypothesis 2D & LP will positively relate to JS & 0.40 & $\mathrm{H}_{2 \mathrm{D}}$ Supported \\
\hline & Hypotheses Related to Person-Organization Fit & \\
\hline Hypothesis 3A & SL will positively relate to POF & 0.45 & $\mathrm{H}_{3 \mathrm{~A}}$ Supported \\
Hypothesis 3B & FF will positively relate to POF & 0.42 & $\mathrm{H}_{3 \mathrm{~B}}$ Supported \\
Hypothesis 3C & GO will positively relate to POF & 0.43 & $\mathrm{H}_{3 \mathrm{C}}$ Supported \\
Hypothesis 3D & LP will positively relate to POF & 0.42 & $\mathrm{H}_{3 \mathrm{D}}$ Supported \\
\hline & Hypotheses Related to Leadership Effectiveness & \\
\hline Hypothesis 4A & SL will positively relate to LE & 0.87 & $\mathrm{H}_{4 \mathrm{~A}}$ Supported \\
Hypothesis 4B & FF will positively relate to LE & 0.88 & $\mathrm{H}_{4 \mathrm{~B}}$ Supported \\
Hypothesis 4C & GO will positively relate to LE & 0.78 & $\mathrm{H}_{4 \mathrm{C}}$ Supported \\
Hypothesis 4D & LP will positively relate to LE & 0.75 & $\mathrm{H}_{4 \mathrm{D}}$ Supported \\
\hline
\end{tabular}

Each of these hypotheses are supported by moderate to strong correlations. The lowest correlation was 0.40 . The highest correlation was 0.88 . All correlations were statistically significant at the $<0.001$ level, exceeding the acceptable standard for two-tailed significance of $<0.01$.

\subsection{Results from Regression Analyses}

Because the correlation analysis supported each of the four primary hypotheses and each of the associated sub-hypotheses, regression analyses were utilized to test the predictive impact of the independent variables on the dependent variables. Multiple regression and hierarchical regression analyses were used to further test the hypotheses.

\subsubsection{Results from Multiple Linear Regression Analyses}

Based on multiple linear regression analyses, each of the PLI subscales significantly predicted organizational commitment, job satisfaction, person-organization fit, and leadership effectiveness. The three predictors (follower-focus, goal-orientation, and leader purposefulness) explained $35.8 \%$ of the variance in organizational commitment, $19.8 \%$ of the variance in job satisfaction, $20.8 \%$ of the variance in person-organization fit, and $78.5 \%$ of the variance in leadership effectiveness. An overview of the $\beta, R^{2}$, and $F$ values is provided in Table 8 . 
Table 8. Results from Multiple Linear Regression.

\begin{tabular}{|c|c|c|c|c|}
\hline & $\begin{array}{c}\text { Organizational } \\
\text { Commitment }\end{array}$ & Job Satisfaction & Person-Org. Fit & $\begin{array}{c}\text { Leadership } \\
\text { Effectiveness }\end{array}$ \\
\hline Follower-Focus & $\beta=0.35^{* * *}$ & $\beta=0.21^{* * *}$ & $\beta=0.11^{*}$ & $\beta=0.70^{* * *}$ \\
\hline Goal-Orientation & $\beta=0.16^{* * *}$ & $\beta=0.16^{* * *}$ & $\beta=0.21^{* * *}$ & $\beta=0.18^{* * *}$ \\
\hline Leader Purposefulness & $\beta=0.12^{* *}$ & $\beta=0.11^{* *}$ & $\beta=0.18^{* * *}$ & $\beta=0.04 *$ \\
\hline$R^{2}$ & 0.36 & 0.20 & 0.21 & 0.79 \\
\hline$F$ & $319.22 * * *$ & $142.13^{* * *}$ & $150.56^{* * *}$ & $2099.59 * * *$ \\
\hline
\end{tabular}

When comparing the Beta scores within each of the multiple regression models, indications of relative importance for each of the independent variables may be inferred from the data. For the following dependent variables (Organizational Commitment, Job Satisfaction, and Leadership Effectiveness), while each of the independent variables were statistically significant predictors, the relative importance of the independent variables was consistent across each model with leader follower-focus having the largest effect, leader goal-orientation having the second largest effect, and leader purposefulness having the third largest effect. The one exception to this was person-organization fit. For POF, the relative importance of the independent variables was leader goal-orientation having the largest effect, leader purposefulness having the second largest effect, and leader follower-focus having the third largest effect. It is also noteworthy that follower focus has an inordinately large effect on leadership effectiveness $(\beta=0.70, p<0.001)$ in comparison to goal orientation $(\beta=0.18, p<0.001)$ and leader purposefulness $(\beta=0.04, p<0.05)$.

\subsubsection{Results from Hierarchical Regression Analyses}

In addition to multiple linear regression, hierarchical regression analyses were conducted in order to test the incremental validity of each of the PLI subscales. As indicated below in Table 13, all $R$ square change results were significant at a level of $<0.001$. Because special focus was given in this study to the unique and incremental value of leader purposefulness, the researchers provide detailed findings related to leader purposefulness first before the other subscales.

Table 9 provides an overview of the incremental validity of leader purposefulness as a predictor of organizational commitment.

Table 9. Summary of Hierarchical Regression Analysis for Predicting Organizational Commitment.

\begin{tabular}{|c|c|c|c|c|c|c|}
\hline & \multicolumn{3}{|c|}{ Model 1} & \multicolumn{3}{|c|}{ Model 2} \\
\hline & $B$ & $S E B$ & $\beta$ & $B$ & $S E B$ & $\beta$ \\
\hline Follower-Focus & 0.316 & 0.025 & $0.421^{* * *}$ & 0.264 & 0.029 & $0.351^{* * *}$ \\
\hline Goal-Orientation & 0.160 & 0.026 & $0.201^{* * *}$ & 0.130 & 0.028 & $0.163^{* * *}$ \\
\hline Leader Purposefulness & & & & 0.119 & 0.034 & $0.123^{* *}$ \\
\hline$R^{2}$ & 0.355 & & & 0.359 & & \\
\hline$\Delta R^{2}$ & 0.355 & & & 0.005 & & \\
\hline$F$ & $469.765 * * *$ & & & $319.224^{* * *}$ & & \\
\hline
\end{tabular}

Table 10 provides an overview of the incremental validity of leader purposefulness as a predictor of job satisfaction. 
Table 10. Summary of Hierarchical Regression Analysis for Predicting Job Satisfaction.

\begin{tabular}{|c|c|c|c|c|c|c|}
\hline & \multicolumn{3}{|c|}{ Model 1} & \multicolumn{3}{|c|}{ Model 2} \\
\hline & $B$ & $S E B$ & $\beta$ & $B$ & $S E B$ & $\beta$ \\
\hline Follower-Focus & 0.199 & 0.027 & $0.274^{* * *}$ & 0.155 & 0.031 & $0.213^{* * *}$ \\
\hline Goal-Orientation & 0.148 & 0.028 & $0.191^{* * *}$ & 0.123 & 0.030 & $0.159^{* * *}$ \\
\hline Leader Purposefulness & & & & 0.100 & 0.037 & $0.107^{* *}$ \\
\hline$R^{2}$ & 0.196 & & & 0.200 & & \\
\hline$\Delta R^{2}$ & 0.196 & & & 0.003 & & \\
\hline$F$ & $208.780 * * *$ & & & $142.131^{* * *}$ & & \\
\hline
\end{tabular}

Table 11 provides an overview of the incremental validity of leader purposefulness as a predictor of job person-organization fit.

Table 11. Summary of Hierarchical Regression Analysis for Predicting Person-Organization Fit.

\begin{tabular}{|c|c|c|c|c|c|c|}
\hline & \multicolumn{3}{|c|}{ Model 1} & \multicolumn{3}{|c|}{ Model 2} \\
\hline & $B$ & $S E B$ & $\beta$ & $B$ & $S E B$ & $\beta$ \\
\hline Follower-Focus & 0.117 & 0.021 & $0.210^{* * *}$ & 0.061 & 0.024 & $0.110 *$ \\
\hline Goal-Orientation & 0.154 & 0.022 & $0.260^{* * *}$ & 0.122 & 0.023 & $0.206^{* * *}$ \\
\hline Leader Purposefulness & & & & 0.126 & 0.028 & $0.176^{* * *}$ \\
\hline$R^{2}$ & 0.200 & & & 0.209 & & \\
\hline$\Delta R^{2}$ & 0.200 & & & 0.009 & & \\
\hline$F$ & $213.59 * * *$ & & & $150.564^{* * *}$ & & \\
\hline
\end{tabular}

Table 12 provides an overview of the incremental validity of leader purposefulness as a predictor of leadership effectiveness.

Table 12. Summary of Hierarchical Regression Analysis for Predicting Leadership Effectiveness.

\begin{tabular}{|c|c|c|c|c|c|c|}
\hline & & Model 1 & & & Model 2 & \\
\hline & $B$ & $S E B$ & $\beta$ & $B$ & $S E B$ & $\beta$ \\
\hline Follower-Focus & 0.592 & 0.016 & $0.721^{* * *}$ & 0.572 & 0.018 & $0.697^{* * *}$ \\
\hline Goal-Orientation & 0.169 & 0.017 & $0.194 * * *$ & 0.158 & 0.018 & $0.181^{* * *}$ \\
\hline Leader Purposefulness & & & & 0.045 & 0.022 & $0.043 *$ \\
\hline$R^{2}$ & 0.785 & & & 0.786 & & \\
\hline$\Delta R^{2}$ & 0.785 & & & 0.001 & & \\
\hline$F$ & $3143.091^{* * *}$ & & & $2099.586^{* * *}$ & & \\
\hline
\end{tabular}

In addition to the above hierarchical regression analyses, hierarchical regression analyses were also conducted on the other two subscales (follower-focus and goal-orientation) for predicting each of the dependent variables (organizational commitment, job satisfaction, person-organization fit, and leadership effectiveness). For economy of space, additional individual hierarchical regression tables will not be reported here. However, Table 13 provides a summary of the $R$ square change values for each of the hierarchical regression analyses conducted. 
Table 13. Summary of $R$ Square Change from Hierarchical Regression Analyses.

\begin{tabular}{ccccc}
\hline & $\begin{array}{c}\text { Organizational } \\
\text { Commitment }\end{array}$ & Job Satisfaction & $\begin{array}{c}\text { Person- } \\
\text { Organization Fit }\end{array}$ & $\begin{array}{c}\text { Leadership } \\
\text { Effectiveness }\end{array}$ \\
\hline Follower-Focus & 0.031 & 0.011 & 0.003 & 0.121 \\
Goal-Orientation & 0.008 & 0.008 & 0.013 & 0.010 \\
Leader Purposefulness & 0.001 & 0.003 & 0.009 & 0.001 \\
\hline
\end{tabular}

All significant at the level of $<0.001$.

The $R$ square change results support each of the sub-hypotheses as all models and associated $R$ square change findings were significant at a level of $<0.001$. The $R$ square change results also support the relative importance findings reported in Section 6.3.1; follower-focus has the largest predictive effect on organizational commitment, job satisfaction, and leadership effectiveness, whereas follower-focus has the third largest predictive effect on person-organization fit. Goal-orientation and leader purposefulness have more limited $R$ square change results, but are statistically significant at these lower levels.

\section{Discussion}

\subsection{Summary of Study Findings}

The study began with the following research question: Does the Purpose in Leadership Inventory [2], both its composite measure of servant leadership and its subscales (leader follower-focus, leader goal-orientation, and leader purposefulness), evidence criterion validity with important work-related outcomes? To answer this question, four primary hypotheses $(1 \mathrm{~A}, 2 \mathrm{~A}, 3 \mathrm{~A}$, and $4 \mathrm{~A})$ and twelve associated sub-hypotheses were evaluated based on the following analyses: (1) exploratory factor analysis; (2) correlation analysis; (3) multiple linear regression analysis; and (4) hierarchical regression analysis.

The findings from these analyses support the study hypotheses. The exploratory factor analysis supported the use of the PLI as a three-dimensional measure, and both the composite measure of servant leadership and each of the three subscales predictably related to important work-related outcomes. The correlation analysis yielded statistically significant positive relationships supporting each of the four primary hypotheses and each of the sub-hypotheses.

The multiple linear regression analyses further supported the PLI subscales predicting important work-related outcomes and yielded statistically significant models. Evaluating the Beta scores, all statistically significant, from the multiple regression models indicated that follower-focus has the largest predictive effect for organizational commitment, job satisfaction, and leadership effectiveness, and that goal-orientation and leader purposefulness have a larger predictive effect on person-organization fit than follower-focus. Finally, hierarchical regression analyses further supported the hypotheses indicating that each of the PLI subscales have a statistically significant incremental effect on the four work-related outcomes measured. Evaluating the $R$ square change scores for each combination of PLI subscales and the work-related outcome variables supported the findings noted above from the analysis of Beta scores. While follower-focus contributes most dominantly in predicting the work-related outcomes studied, goal-orientation and leader purposefulness are also supported as statistically significant predictors of the studied work-related outcomes at a smaller level.

\subsection{Discussion of Study Findings}

Beyond this initial overview of the study findings, the study results warrant additional discussion. First, regarding job satisfaction, the study findings, which support the relationship of servant leadership and follower job satisfaction, are consistent with previous studies in the servant leadership literature. The positive effect of servant leadership on job satisfaction is also reported by Laub [11], Hebert [17], Drury [52], Irving [19,20], Mayer et al. [18], West et al. [53], Jaramillo et al. [49], Sun and 
Wang [66], and van Dierendonck and Nuijten [9]. The present study affirms that servant leadership, leader follower-focus, leader goal-orientation, and leader purposefulness are correlated with and predictors of follower job satisfaction.

Second, regarding organizational commitment, the study findings, which support the relationship of servant leadership and follower organizational commitment, are consistent with previous studies in the servant leadership literature. The positive effect of servant leadership on organizational commitment is also reported by Dannhauser and Boshoff [50], Liden et al. [16], Jaramillo et al. [49], Drury [63], Asag-gau and van Dierendonck [51], and van Dierendonck and Nuijten [9]. Discussing the rationale behind the relationship between servant leadership and organizational commitment, Liden et al. argue from social exchange theory that "subordinates may be motivated to respond in kind to their leader's extra efforts by evincing increased commitment to the organization" [16] (p. 174). A similar argument may be made for explaining the relationship of these variables in the current study. In fact, the strongest correlations found among the three follower-oriented dependent variables are the correlations related to organizational commitment. This affirms that servant leadership, leader follower-focus, leader goal-orientation, and leader purposefulness hold particular importance for follower organizational commitment.

Third, the study findings supporting the relationship of servant leadership and follower person-organization fit, though seen in only a limited manner in the literature, are consistent with the literature. Jaramillo et al. [54] found a positive relationship between servant leadership and person-organization fit (0.66). Fields notes that, "person-organization fit refers to the degree of congruence or compatibility between the attributes of an organization member and those of the organization" [67] (p. 217). Similar to the arguments made above about organizational commitment, when a follower sees the organization through the lens of the servant leadership behaviors of their leader, the results of this study point to such leader behaviors having a positive relationship to a follower's sense of fitting in the organization of which they are part. The present study affirms that servant leadership, leader follower-focus, leader goal-orientation, and leader purposefulness are correlated with and predictors of follower person-organization fit.

Fourth, regarding leadership effectiveness, among the four dependent variables, leadership effectiveness demonstrated the strongest relationship with servant leadership. Overall, servant leadership, leader follower-focus, leader goal-orientation, and leader purposefulness are strongly correlated with follower perceptions of servant leadership. These findings support the relationship between servant leadership and leadership effectiveness found in previous studies $[2,58]$. Regression analyses further support each of the independent variables as significant predictors of leadership effectiveness, though leader follower-focus has the largest incremental effect on leadership effectiveness.

Fifth, based on the literature noted in the previous discussion points, the fact that job satisfaction, organizational commitment, person-organization fit, and leadership effectiveness are also positively related to the measures of servant leadership in the Purpose in Leadership Inventory provides criterion-related validity for the Purpose in Leadership Inventory as a measure of servant leadership. An exploratory factor analysis was conducted on the Purpose in Leadership Inventory in which factor loadings less than 0.30 were suppressed. The factor analysis confirmed leader follower-focus, leader goal-orientation, and leader purposefulness scales with a 22-item solution (see Table 5 and presentation of results in Section 6.1). Irving's 24-Item PLI instrument, from which the 22-item solution is drawn, is included in Appendix A. The two items unintentionally omitted in the present study are indicated in Appendix A.

This 22-item measure for servant leadership used in this study performed as hypothesized in reference to job satisfaction, organizational commitment, person-organization fit, and leadership effectiveness. The previous and current exploratory factor analyses support using the subscales of the instrument. Additionally, the high reliability coefficients point toward the value of utilizing the instrument as a collective measure of servant leadership as well. Other valid and reliable measures of 
servant leadership exist (e.g., [9,11,13-16,22]). The Purpose in Leadership Inventory has great potential when used in combination with other servant leadership measures due to its intentional emphasis on leader purposefulness as part of servant leadership, something only implicitly represented by other servant leadership approaches and measures. The Purpose in Leadership Inventory provides a means for explicitly measuring leader purposefulness in future studies.

Sixth, based on the multiple regression analyses conducted, leader follower-focus had the largest predictive effect on a majority of the dependent variables included in the study (see Table 13 and Section 6.3.1). The servant leadership literature review noted above in Section 2 of this article emphasized focus on followers as a key distinguishing mark of servant leadership. The findings of this study affirm the importance of leader follower-focus. Leader follower-focus had the largest Beta and $R$ square change scores in reference to other independent variables when examined as a predictor of organizational commitment, job satisfaction, and leadership effectiveness. The Purpose in Leadership Inventory provides a means for explicitly measuring follower-focus in future studies.

Finally, the measure of leader purposefulness within the Purpose in Leadership Inventory is perhaps the most unique contribution this study offers to the servant leadership literature. As job satisfaction $[9,11,17-20,49,52,53,66]$, organizational commitment $[9,16,49-52]$, person-organization fit [54], and leadership effectiveness [2,58] have been previously related to servant leadership in the literature, it is the servant leadership measure of leader purposefulness that provides a unique and original contribution to empirical servant leadership studies. The Purpose in Leadership Inventory provides a means for expanding the research stream on this important leader area.

As noted in the introduction, special focus was given to the unique and incremental value of leader purposefulness in this study. Leader purposefulness played a statistically significant role in predicting the studied work-related outcomes, but the incremental effect was comparatively very small. These findings point to the need for more research surrounding the effect of leader purposefulness. While the study findings provide empirical support for leader purposefulness as a factor to include as part of servant leadership theory and research, in reference to follower-focus the incremental effect is modest. This affirms leader follower-focus as a dominate servant leadership factor in comparison to goal-orientation and leader purposefulness, but also draws attention to the need to explore the relationship between these variables in further detail.

\section{Study Limitations and Recommendations for Future Research}

\subsection{Study Limitations}

First, the researchers used a cross-sectional design. While this provided an efficient means for gathering data at a specific point in time, the data was drawn across diverse segments of the population of the healthcare organization studied and the data collected provides no way of evaluating the effect of servant leadership over a period of time.

Second, as a study utilizing a newer measure of servant leadership, including other measures of servant leadership in the study for direct comparison would have strengthened the study design, particularly for assessing convergent validity. This was not done due to the length of the total survey already and the related desire to maintain strong response rates by limiting the total instruments engaged by participants to one measure per variable. As a means of addressing this, other studies, using other servant leadership instruments, were engaged in the literature review and discussion sections as points of comparison to the present study.

Third, the six items of the leadership effectiveness scale were developed by Ehrhart and Klein [67], and were used in Irving's 2014 [2] study. Unfortunately, due to an error in inputting the items into Qualtrics, only four of the six items were included in the present study. The measure did perform as anticipated. The reliability coefficient for the four-item scale was 0.88 , and was similar compared to the 0.90 in the six-item scale included in the Irving [2] study. Additionally, leadership effectiveness was positively correlated as a dependent variable to servant leadership. All of these positive relationships 
were significant at $<0.001$, and these correlations were similar to the positive correlations found in the Irving study.

Fourth, also due to an error in inputting the items into Qualtrics, only 22 of the 24 items from the Purpose in Leadership Inventory were included in the present study. The 22 items were loaded in a similar fashion to the initial factory analysis reported by Irving [2]. As previously noted, Irving's 24-Item PLI instrument, from which the 22-item solution was drawn, is included in Appendix A along with indications of which two items were omitted. For future studies, the authors recommend utilizing the original 24-item PLI for two reasons. First, because all the other items performed as anticipated in the current study, it can be anticipated that the two omitted items would likewise perform as expected. Second, the two omitted items included one item from the goal-orientation subscale and one item from the leader purposefulness subscale. Because these subscales do not have as many items as follower-focus, adding these two items back into future studies will strengthen the subscales in reference to follower-focus.

\subsection{Recommendations for Future Research}

The present study opens up several pathways for future research. First, as this study was conducted in the healthcare sector of the U.S. context, other studies would benefit from examining similar variables in other organizational and cultural contexts. Second, the dependent variables evaluated in this study included job satisfaction, organizational commitment, person-organization fit, and leadership effectiveness. In future servant leadership research, it would be helpful both to add new follower and organizational variables in order to examine the effect of servant leadership on these variables, and to expand the research thread on servant leadership and person-organization fit, which has more limited support in the literature.

Finally, since the measure of and findings related to leader purposefulness utilized in this study were the most original contributions to servant leadership studies, the Purpose in Leadership Inventory provides a pathway for expanding this thread of research on the effect of leader purposefulness for servant leadership researchers. Leader purposefulness has a strong historic presence in the leadership literature noted earlier in this article. The present empirical study emphasizes the relevance of leader purposefulness as a component within servant leadership studies. The Purpose in Leadership Inventory used alongside other servant leadership measures provides a pathway for explicitly incorporating leader purposefulness into future studies. The researchers hope to see an expanding research thread that will engage leader purposefulness as an important dimension in ongoing servant leadership research.

Author Contributions: This paper is the collaborative work of Irving and Berndt. Berndt provided the primary contact with the organization included in the study and was the lead for collecting the data. Irving was the lead for identifying study instruments, analyzing the data, and writing the manuscript. Both researchers read, edited, and approved the final manuscript.

Conflicts of Interest: The authors declare no conflict of interest.

\section{Appendix A. The Purpose in Leadership Inventory (PLI)}

The Purpose in Leadership Inventory is designed as a tool to measure follower perspectives of leader attitudes and focus. Please consider one current or past leader as you take this inventory, and respond to each of the 24 items based on the extent to which you disagree or agree with the statement. Thank you for taking a few minutes to share your feedback. 


\begin{tabular}{|c|c|c|c|c|c|c|}
\hline PART I & $\begin{array}{l}\text { Strongly } \\
\text { Disagree }\end{array}$ & Disagree & $\begin{array}{l}\text { Somewhat } \\
\text { Disagree }\end{array}$ & $\begin{array}{l}\text { Somewhat } \\
\text { Agree }\end{array}$ & Agree & $\begin{array}{l}\text { Strongly } \\
\text { Agree }\end{array}$ \\
\hline 1-My leader values people. & $\bigcirc$ & $\bigcirc$ & $\bigcirc$ & $\bigcirc$ & $\bigcirc$ & $\bigcirc$ \\
\hline $\begin{array}{l}\text { 2-My leader is committed to loving and caring } \\
\text { for followers. }\end{array}$ & O & O & 0 & 0 & 0 & O \\
\hline $\begin{array}{l}\text { 3-My leader values the individuality } \\
\text { of followers. }\end{array}$ & 0 & O & O & $\bigcirc$ & 0 & 0 \\
\hline 4-My leader is focused on the needs of followers. & O & O & O & O & O & O \\
\hline 5-My leader values followers. & O & $\mathrm{O}$ & $\mathrm{O}$ & $\mathrm{O}$ & O & 0 \\
\hline $\begin{array}{l}\text { 6-My leader understands how to } \\
\text { encourage followers. }\end{array}$ & O & 0 & O & O & 0 & O \\
\hline $\begin{array}{l}\text { 7-My leader understands how to relate well } \\
\text { with people. }\end{array}$ & O & O & O & O & O & 0 \\
\hline $\begin{array}{l}\text { 8-My leader values the uniqueness of } \\
\text { individuals in our organization. }\end{array}$ & 0 & 0 & 0 & 0 & 0 & 0 \\
\hline $\begin{array}{l}\text { 9-My leader is committed to seeing potential } \\
\text { in people. }\end{array}$ & O & O & 0 & O & 0 & O \\
\hline PART II & $\begin{array}{l}\text { Strongly } \\
\text { Disagree }\end{array}$ & Disagree & $\begin{array}{l}\text { Somewhat } \\
\text { Disagree }\end{array}$ & $\begin{array}{l}\text { Somewhat } \\
\text { Agree }\end{array}$ & Agree & $\begin{array}{l}\text { Strongly } \\
\text { Agree }\end{array}$ \\
\hline 10-My leader focuses on task accomplishment. & $\mathrm{O}$ & 0 & O & O & 0 & $\mathrm{O}$ \\
\hline 11-My leader understands how to be efficient. & O & O & O & $\mathrm{O}$ & O & O \\
\hline 12-My leader knows how to get things done. & O & O & O & O & O & O \\
\hline 13-My leader values excellence*. & O & 0 & 0 & 0 & 0 & 0 \\
\hline $\begin{array}{l}\text { 14-My leader understands how to } \\
\text { formulate strategies. }\end{array}$ & 0 & 0 & 0 & 0 & 0 & 0 \\
\hline $\begin{array}{l}\text { 15-My leader does not allow distractions to } \\
\text { interfere with the achievement of important } \\
\text { organizational goals. }\end{array}$ & 0 & 0 & 0 & 0 & 0 & 0 \\
\hline $\begin{array}{l}\text { 16-My leader understands the importance of } \\
\text { reviewing results in order to improve } \\
\text { future performance. }\end{array}$ & 0 & 0 & 0 & 0 & 0 & 0 \\
\hline $\begin{array}{l}\text { 17-My leader is able to stay focused of } \\
\text { organizational goals. }\end{array}$ & 0 & 0 & 0 & 0 & 0 & 0 \\
\hline PART III & $\begin{array}{l}\text { Strongly } \\
\text { Disagree }\end{array}$ & Disagree & $\begin{array}{l}\text { Somewhat } \\
\text { Disagree }\end{array}$ & $\begin{array}{l}\text { Somewhat } \\
\text { Agree }\end{array}$ & Agree & $\begin{array}{l}\text { Strongly } \\
\text { Agree }\end{array}$ \\
\hline $\begin{array}{l}\text { 18-My leader believes in the purpose of } \\
\text { our organization. }\end{array}$ & 0 & 0 & 0 & 0 & 0 & 0 \\
\hline $\begin{array}{l}\text { 19-My leader believes that what our } \\
\text { organization does matters. }\end{array}$ & 0 & 0 & 0 & 0 & O & 0 \\
\hline $\begin{array}{l}\text { 20-My leader sees the importance of our } \\
\text { organization's mission in light of a larger sense } \\
\text { of purpose. }\end{array}$ & 0 & 0 & 0 & 0 & 0 & 0 \\
\hline $\begin{array}{l}\text { 21-My leader understands how his/her personal life's } \\
\text { purpose connects to the organization's purpose*. }\end{array}$ & 0 & 0 & 0 & 0 & 0 & 0 \\
\hline $\begin{array}{l}\text { 22-My leader believes we are committed to a } \\
\text { vision that is bigger than any one person. }\end{array}$ & 0 & 0 & 0 & 0 & 0 & 0 \\
\hline $\begin{array}{l}\text { 23-My leader understands the place of our } \\
\text { organization in the broader community outside of } \\
\text { the organization. }\end{array}$ & 0 & 0 & 0 & 0 & 0 & 0 \\
\hline $\begin{array}{l}\text { 24-My leader understands his/her personal } \\
\text { life purpose. }\end{array}$ & 0 & 0 & 0 & 0 & 0 & 0 \\
\hline
\end{tabular}

* The 24-Items above are from Irving's [2] study. The two italicized items above were unintentionally omitted from the current study.

\section{References}

1. Greenleaf, R.K. Servant Leadership: A Journey into the Nature of Legitimate Power and Greatness; Paulist Press: New York, NY, USA, 1977.

2. Irving, J.A. The development \& initial testing of the purpose in leadership inventory: A tool for assessing leader goal-orientation, follower-focus, and purpose-in-leadership. SLTP 2014, 1, 52-66.

3. Matteson, J.A.; Irving, J.A. Servant versus self-sacrificial leadership: Commonalities and distinctions of two follower-oriented leadership theories. Int. J. Leadersh. Stud. 2005, 2, 36-51. 
4. Stone, A.G.; Patterson, K.; Russell, R.F. Transformational versus servant leadership: A difference in leader focus.(author abstract). Leadersh. Organ. Dev. J. 2004, 25, 349-361. [CrossRef]

5. Gibson, C.B.; Birkinshaw, J. The antecedents, consequences, and mediating role or organizational ambidexterity. Acad. Manag. J. 2004, 47, 209-226. [CrossRef]

6. Sun, P.Y.T. The servant identity: Influences on the cognition and behavior of servant leaders. Leadersh. $Q$. 2013, 24, 544-557. [CrossRef]

7. Humphreys, J.H. Contextual implications for transformational and servant leadership: A historical investigation. Manag. Decis. 2005, 43, 1410-1431. [CrossRef]

8. Wong, P.T.P.; Page, D. Servant leadership: An opponent-process model and the revised servant leadership profile. In Proceedings of the Servant Leadership Research Roundtable, Regent University, Virginia Beach, VA, USA, August 2003.

9. Van Dierendonck, D.; Nuitjen, I. The servant leadership survey: Development and validation of a multi-dimensional measure. J. Bus. Psychol. 2011, 26, 249-267. [CrossRef] [PubMed]

10. Farling, M.; Stone, A.; Winston, B. Servant leadership: Setting the stage for empirical research. J. Leadersh. Organ. Stud. 1999, 6, 1-2. [CrossRef]

11. Laub, J.A. Assessing the Servant Organization: Development of the Servant Organizational Leadership (SOLA) Instrument. Ph.D. Dissertation, Florida Atlantic University, Boca Raton, FL, USA, 1999.

12. Page, D.; Wong, P.T.P. A conceptual framework for measuring servant leadership. In The Human Factor in Shaping the Course of History and Development; Adjibolooso, S., Ed.; American University Press: Washington, DC, USA, 2000; pp. 69-110.

13. Dennis, R.S.; Bocarnea, M. Development of the servant leadership assessment instrument. Leadersh. Organ. Dev. J. 2005, 26, 600-615. [CrossRef]

14. Barbuto, J.E., Jr.; Wheeler, D.W. Scale development and construct clarification of servant leadership. Group Organ. Manag. 2006, 31, 300-326. [CrossRef]

15. Sendjaya, S.; Sarros, J.C.; Santora, J.C. Defining and measuring servant leadership behavior in organizations. J. Manag. Stud. 2008, 45, 402-424. [CrossRef]

16. Liden, R.C.; Wayne, S.J.; Zhao, H.; Henderson, D. Servant leadership: Development of a multidimensional measure and multi-level assessment. Leadersh. Q. 2008, 19, 161-177. [CrossRef]

17. Hebert, S.C. The relationship of perceived servant leadership and job satisfaction from the follower's perspective. Proc. Am. Soc. Bus. Behav. Sci. 2004, 11, 685-697.

18. Mayer, D.M.; Bardes, M.; Piccolo, R.F. Do servant-leaders help satisfy follower needs? An organizational justice perspective. Eur. J. Work Organ. Psychol. 2008, 17, 180-197. [CrossRef]

19. Irving, J.A. Servant leadership and the effectiveness of teams: Findings and implications. In Proceedings of the Servant Leadership Research Roundtable, Regent University, Virginia Beach, VA, August 2004.

20. Irving, J.A. Servant leadership and the effectiveness of teams. Diss. Abstr. Int. 2005, 66, 1421.

21. Walumbwa, F.O.; Hartnell, C.A.; Oke, A. Servant leadership, procedural justice climate, service climate, employee attitudes, and organizational citizenship behavior: A cross-level investigation. J. Appl. Psychol. 2010, 95, 517-529. [CrossRef] [PubMed]

22. Liden, R.C.; Wayne, S.J.; Meuser, J.D.; Hu, J.; Wa, J.; Liao, C. Servant leadership: Validation of a short form of the sl-28. Leadersh. Q. 2015, 26, 254-269. [CrossRef]

23. Hu, J.; Liden, R.C. Antecedents of team potency and team effectiveness: Examination of goal and process clarity of servant leadership. J. Appl. Psychol. 2011, 96, 851-862. [CrossRef] [PubMed]

24. Irving, J.A.; Longbotham, G.J. Team effectiveness and six essential servant leadership themes: A regression model based on items in the organizational leadership assessment. Int. J. Leadersh. Stud. 2007, 2, 98-114.

25. Peterson, S.J.; Galvin, B.M.; Lange, D. CEO servant leadership: Exploring executive characteristics and firm performance. Pers. Psychol. 2012, 65, 565-596. [CrossRef]

26. Collins, J.C.; Porras, J. Organizational vision and visionary organizations. Calif. Manag. Rev. 1991, 34, 30-52. [CrossRef]

27. Albrecht, K. The Northbound Train: Finding the Purpose, Setting the Direction, Shaping the Destiny of Your Organization; Amacon: New York, NY, USA, 1994; p. 213.

28. Fry, L.W. Toward a theory of spiritual leadership. Leadersh. Q. 2003, 14, 693-727. 
29. Bordas, J. Power and passion: Finding personal purpose. In Reflections on Leadership: How Robert $k$. Greenleaf's Theory of Servant-Leadership Influenced Today's Top Management Thinkers; Spears, L.C., Ed.; John Wiley \& Sons, Inc.: New York, NY, USA, 1995.

30. George, B. Authentic Leadership: Rediscovering the Secrets to Creating Lasting Value; John Wiley \& Sons: San Francisco, CA, USA, 2003.

31. Wong, P.T.P. Implicit theories of meaningful life and the development of the personal meaning profile. In The Human Quest for Meaning; Wong, P.T.P., Fry, P.S., Eds.; Erlbaum: Mahwah, NJ, USA, 1998.

32. Wong, P.T.P. Is your organization an obstacle or a relay team? A meaning-centered approach to creating a collaborative culture. In Creating a Culture of Collaboration; Schuman, S., Ed.; Jossey-Bass/Wiley: San Francisco, CA, USA, 2006.

33. Wong, P.T.P.; Fry, P.S. The Human Quest for Meaning: A Handbook of Psychological Research and Clinical Applications; Erlbaum: Mahwah, NJ, USA, 1998.

34. Autrey, J.A. Life and Work: A Manager's Search for Meaning, 1st ed.; William Morrow: New York, NY, USA, 1994.

35. Conyne, R.K. Personal experience and meaning in group work leadership: The views of experts. J. Spec. Group Work 1998, 23, 245-256. [CrossRef]

36. Leider, R. The Power of Purpose: Creating Meaning in Your Life and Work, 1st ed.; Berrett-Koehler Publishers: San Francisco, CA, USA, 1997.

37. Terez, T. 22 Keys to Creating a Meaningful Workplace; Adams Media: Holbrook, MA, USA, 2000.

38. Weisbord, M.R. Productive Workplaces: Organizing and Managing for Dignity, Meaning, and Community, 2nd ed.; Jossey-Bass: San Francisco, CA, USA, 2004.

39. Podolny, J.M.; Khurana, R.; Besharov, M.L. Revisiting the meaning of leadership. In Handbook of Leadership Theory and Practice: A Harvard Business School Centennial Colloquium; Nohria, N., Khurana, R., Eds.; Harvard Business Press: Boston, MA, USA, 2010.

40. Fry, L.W.; Slocum, J.W. Maximizing the triple bottom line through spiritual leadership. Organ. Dyn. 2008, 37, 86-96. [CrossRef]

41. Fry, L.W. Introduction to the leadership quarterly special issue: Toward a paradigm of spiritual leadership. Leadersh. Q. 2005, 16, 619-622. [CrossRef]

42. Markow, F.; Klenke, K. The effects of personal meaning and calling on organization commitment: An empirical investigation of spiritual leadership. Int. J. Organ. Anal. 2005, 13, 8-27. [CrossRef]

43. Tepper, B. Organizational citizenship behavior and the spiritual employee. In Handbook of Workplace Spirituality and Organizational Performance; Giacalone, R., Jurkiewics, C., Eds.; M.E. Sharpe: New York, NY, USA, 2003; pp. 181-192.

44. Cash, K.; Gray, G. A framework for accommodating religion and spirituality in the workplace. Acad. Manag. Exec. 2000, 14, 124-133. [CrossRef]

45. Zinnbauer, B.J.; Pargament, K.I.; Scott, A.B. The emerging meanings of religiousness and spirituality: Problems and prospects. J. Personal. 1999, 67, 889-919. [CrossRef]

46. Maddock, R.C.; Fulton, R.L. Motivation, Emotions, and Leadership: The Silent Side of Management; Quorum Books: Westport, CT, USA, 1998.

47. Fleischman, P.R. The Healing Spirit: Explorations in Religion and Psychotherapy; Bonne Chance Press: Cleveland, OH, USA, 1994.

48. Freeman, G.T. Spirituality and servant leadership: A conceptual model and research proposal. Emerg. Leadersh. Journeys 2011, 4, 120-140.

49. Jaramillo, F.; Grissaffe, D.B.; Chonko, L.B.; Roberts, J.A. Examining the impact of servant leadership on sales force performance. J. Pers. Sell. Sales Manag. 2009, 29, 257-275.

50. Dannhauser, Z.; Boshoff, A.B. Structural equivalence of the barbuto and wheeler (2006) servant leadership questionnaire on north american and south african samples. Int. J. Leadersh. Stud. 2007, 2, 148-168.

51. Asag-gau, L.; Van Dierendonck, D. The impact of servant leadership on organizational commitment among the highly talented: The role of challenging work conditions and psychological empowerment. Eur. J. Int. Manag. 2011, 5, 464-483.

52. Drury, S. Employee Perceptions of Servant Leadership: Comparisons by Level and with Job Satisfaction and Organizational Commitment. Ph.D. Thesis, Regent University, Virginia Beach, VA, USA, 2004. 
53. West, G.R.B.; Bocarnea, M.; Maranon, D. Servant-leadership as a predictor of job satisfaction and organizational commitment with the moderating effects of organizational support and role clarity among filippino engineering, manufacturing, and technology workers. Int. J. Servant Leadersh. 2009, 5, 129-162.

54. Jaramillo, F.; Grisaffe, D.B.; Chonko, L.B.; Roberts, J.A. Examining the impact of servant leadership on salesperson's turnover intention. J. Pers. Sell. Sales Manag. 2009, 29, 351-365. [CrossRef]

55. Babakus, E.; Yavas, U.; Ashill, N.J. Service worker burnout and turnover intentions: Roles of person-job fit, servant leadership, and customer orientation. Serv. Mark. Q. 2010, 32, 17-31. [CrossRef]

56. Vondey, M. The relationships among servant leadership, organizational citizenship behavior, person-organization fit, and organizational identification. Int. J. Leadersh. Stud. 2010, 6, 3-27.

57. Cable, D.M.; Judge, T.A. Person-organization fit, job choice decisions, and organizational entry. Organ. Behav. Hum. Decis. Processes 1996, 67, 294-311. [CrossRef]

58. Hale, J.R.; Fields, D.L. Exploring servant leadership across cultures: A study of followers in Ghana and the USA. Leadership 2007, 3, 397-417. [CrossRef]

59. Kramer, R. Leading by listening: An empirical test of Carl Rogers's theory of human relationship using interpersonal assessments of leaders by followers. Diss. Abstr. Int. Sect. A Hum. Soc. Sci. 1997, 58, 514.

60. Bechler, C.; Johnson, S.D. Leadership and listening: A study of member perceptions. Small Group Res. 1995, 26, 77-85. [CrossRef]

61. Lore, J.S. Servant-Leadership in A Christian Organization: The Sisters of St. Joseph Health System. In Insights on Leadership; Spears, L.C., Ed.; Wiley: New York, NY, USA, 1998; pp. $297-307$.

62. Cammann, C.; Fichman, M.; Jenkins, D.; Klesh, J. Assessing the attitudes and perceptions of organizational members. In Assessing Organizational Change: A Guide to Methods, Measures and Practices; Seashore, S., Mirvis, E.L.P., Cammann, C., Eds.; John Wiley: New York, NY, USA, 1983.

63. Balfour, D.; Wechsler, B. Organizational commitment: Antecedents and outcomes in public organizations. Public Prod. Manag. Rev. 1996, 29, 256-277. [CrossRef]

64. Ehrhart, M.G.; Klein, K.J. Predicting followers' preferences for charismatic leadership: The influence of follower values and personality. Leadersh. Q. 2001, 12, 155-179. [CrossRef]

65. Krejcie, R.V.; Morgan, D.W. Determining sample size for research activities. Educ. Psychol. Meas. 1970, 30, 607-610. [CrossRef]

66. Sun, J.M.; Wang, B. Servant leadership in china: Conceptualization and measurement. Adv. Glob. Leadersh. 2009, 5, 321-344.

67. Fields, D.L. Taking the Measure of Work: A Guide to Validated Scales for Organizational Research and Diagnosis; Sage: Newcastle upon Tyne, UK, 2002.

(C) 2017 by the authors. Licensee MDPI, Basel, Switzerland. This article is an open access article distributed under the terms and conditions of the Creative Commons Attribution (CC BY) license (http:/ / creativecommons.org/licenses/by/4.0/). 